PSYCHOLOGIA ROZWOJOWA, $2017 *$ tom 22, nr 3, s. 25-34

doi:10.4467/20843879PR.17.014.7574

www.ejournals.eu/Psychologia-Rozwojowa

MARIAN OLEJNIK

Akademia Ignatianum, Kraków

University Ignatianum, Kraków

e-mail: marian.olejnik@ignatianum.edu.pl

\title{
Kategoria rozwoju w psychologii life-span i jej metodologiczne implikacje
}

\section{The Category of Development in Life-span Psychology and Its Methodological Implications}

\begin{abstract}
The subject of this paper is the concept of development in life span psychology. The claim was put forward that the picture of human development presented by contemporary developmental psychology is unsatisfactory, and that the reason for this is the incompatibility of the methodological paradigm of natural sciences adopted by psychology with the specificity of the object of study of developmental psychology. An analysis of the nature of development within Bernard Kaplan's genetic-dramatism perspective and John R. Searle's theory of mind and social reality was presented. Also, its methodological implications were delineated, drawing attention to the attempt of both perspectives to coordinate the logic of cause and effect with the one of intention, purposes and aims in studying human development.
\end{abstract}

Key words: development, intentionality, teleology, genetic-dramatism perspective.

Słowa kluczowe: rozwój, intencjonalność, teleologia, perspektywa genetyczno-dramatyczna.

\section{WPROWADZENIE}

Istotnym elementem refleksji nad stanem współczesnej psychologii rozwojowej jest poczucie niedosytu związane z brakiem jednoznacznych osiągnięć i wyraźnego postępu na drodze do zrozumienia natury procesu rozwoju psychicznego człowieka (Broughton, 1987; Burman, 1994; Hook, 2004; Kaplan, 1983b). Oczywiście nie ma ono związku ze zmniejszaniem się liczby prac teoretycznych i badawczych czy też z mniejszym wyrafinowaniem prezentowanych analiz teoretycznych lub stosowanych procedur badawczych. Liczba publikacji z roku na rok jest coraz większa, podobnie jak stopień ich tematycznego zróżnicowania oraz metodologicznego zaawansowania (Krampen, von Eye, Schui, 2011), niemniej ewidentny postęp i proliferacja dokonań w tym zakresie nie przekładają się na konstrukcję spójnego wewnętrznie obrazu rozwoju człowieka. Ten niedosyt jest szczególnie wyraźny w kontekście osiągnięć, jakie odnotowują nauki o przyrodzie, a niewielką pociechą wydaje się to, że na tle przyrodoznawstwa równie mizernie jak psychologia rozwojowa wypadają inne nauki społeczne i humanistyczne. Już ponad pół wieku temu Susan Langer (1957) w swojej pracy Philosophy in a New Key. A Study in the Symbolism of Reason, Rite, and Art wystawiła surową ocenę psychologii jako nauce. Pomimo upływu lat jej uwagi wydają się $\mathrm{w}$ dalszym ciągu aktualne:

myśl twórcza, która zrodziła fizykę i chemię oraz ich potomstwo - technikę, medycynę, biologię - jest pozbawiona jakichkolwiek ożywczych pojęć, jeśli chodzi o nauki humanistyczne. Schematy fizyków, tak wiernie naśladowane przez 
całe pokolenia psychologów, epistemologów i estetyków, najprawdopodobniej wstrzymują ich postęp, uniemożliwiając swym szkodliwym szablonem ewentualne poznanie. Schemat nie jest fałszywy - jest on absolutnie słuszny - lecz nieprzydatny do badań zjawisk psychologicznych. Nie rodzi on pytań przewodnich i nie pobudza konstruktywnej wyobraźni, jak to ma miejsce w badaniach z zakresu fizyki. Schematy te nie dostarczają metody, wywołują natomiast spory metodologiczne (Langer, 1976, s. 68-69).

Powstaje pytanie, jaka jest przyczyną tego stanu rzeczy. Czy rację ma Langer, która źródeł kryzysu psychologii upatruje w przeniesieniu paradygmatu badawczego przyrodoznawstwa na grunt nauk społecznych i humanistycznych i tam jego powielaniu w sposób rutynowy i bezrefleksyjny? Czy też źródeł należy szukać w innym miejscu? Intencją niniejszych rozważań jest zarysowanie podstaw do odpowiedzi na to pytanie.

\section{POJĘCIE ROZWOJU}

Wydaje się, że rozbieżność między dominującym w psychologii paradygmatem metodologicznym, który ma swoje źródło w przyrodoznawstwie, a naturą przedmiotu jej zainteresowania jest szczególnie wyraźna w dziedzinie rozważań nad rozwojem człowieka.

Wspólnym elementem zdecydowanej większości definicji proponowanych na gruncie współczesnej psychologii rozwojowej jest teza, że rozwój to proces zmian, którym podlega jednostka (jej zachowanie, psychika). Tego rodzaju definicja jest oczywiście niekompletna, ponieważ kłóci się z oczywistą intuicją, że nie każda zmiana ma charakter rozwojowy. Jak zatem odróżnić zmianę rozwojową od nierozwojowej?

Problem z odpowiedzią na to pytanie pojawia się od razu, gdy chcemy określić w sposób jednoznaczny obiektywne kryteria pozwalające dokonywać tego rodzaju rozróżnień. Przyjmuje się np. jako kryterium możliwość powiązania zmian z jakimś obiektywnym indeksem czasu (Overton, 2006; Schaie, Baltes, 1975; Trempała, 2000). Wedle jednej z tego typu propozycji zmiany mają charakter rozwojowy, gdy można je związać z wiekiem, czasem historycznym lub generacją (Schaie, Baltes, 1975). Obecnie uważa się, że to kryterium jest niewystarczające, ponieważ indeks czasu jako wskaźnik rozwoju wydaje się pozbawiony istotnej treści eksplanacyjnej i jako taki może służyć jedynie rejestracji zmian, co do których zakłada się, że są rozwojowe, ale na podstawie innych dodatkowych kryteriów. Te inne dodatkowe kryteria zazwyczaj odnoszą się do:

- charakteru samej zmiany,

- natury tego, co się zmienia,

- funkcji, jaką zmiana pozwala realizować.

Do pierwszej grupy można zaliczyć kryteria stwarzające możliwość ujęcia zmian w kategoriach wzrostu wyrażonego na skali wartości ciągłych i/lub skokowych (zmiany ilościowe/ jakościowe). Do tej grupy należy również kryterium stałej, niezmiennej kolejności występowania zmian, czy też ich nieodwracalnego i powszechnego charakteru. Drugą grupę reprezentują kryteria, które wskazują na całościowy charakter zmian albo na postępujące różnicowanie oraz hierarchiczną integrację tego, co się zmienia, a więc zachowania i psychiki. Do trzeciej grupy należą takie kryteria, jak np. ukierunkowanie zmian, a więc ich zorientowanie na jakiś dający się zidentyfikować cel stanowiący kulminację rozwoju.

Nietrudno zauważyć, że wymienione grupy kryteriów mają heterogeniczny charakter. Pierwsza grupa obejmuje formalne w swym charakterze kryteria odnoszące się do samej zmiany, dwie pozostałe grupy natomiast odnoszą się do obiektu (systemu, układu), który się zmienia. W wypadku drugiej grupy polega to na zwróceniu uwagi na zmiany struktury, organizacji tego, co się zmienia, a w przypadku trzeciej-na możliwości realizacji jakiejś nowej (rozwojowo) funkcji przez system, który się zmienia. Chcąc przywołać konkretne przykłady zastosowania wymienionych sposobów identyfikowania zmian rozwojowych w odniesieniu do wymienionych trzech grup, można wskazać na:

- rozwojowe koncepcje oparte na teorii (społecznego) uczenia się (np. koncepcja Bandury) w wypadku kryteriów pierwszej grupy; 
- koncepcje stadialne oparte na strukturalnych modelach rozwoju (np. neopiagetowskie teorie rozwoju postformalnej inteligencji operacyjnej) w wypadku kryteriów drugiej grupy;

- stadialne koncepcje oparte na modelach funkcjonalnych (np. teoria psychospołecznego rozwoju ego Erika Eriksona, model rozwoju struktury życia Daniela Levinsona, koncepcja zadań rozwojowych Roberta Havighursta) w wypadku kryteriów ostatniej grupy.

Warto zauważyć, że wszystkie proponowane kryteria wprowadzają - w mniejszym lub większym stopniu wyartykułowany - porządek teleologii do analizy rozwojowego charakteru zmian. Dotyczy to nawet kryteriów pierwszej grupy, które wydają się mieć jednoznacznie formalny charakter. $\mathrm{W}$ ich wypadku porządek ten wprowadza arbitralnie ustalony przez badacza kierunek wzrostu i/albo regresu zmian ilościowych i jakościowych. Przecież z faktu, że zmiany układają się w sekwencję biegnącą w określonym kierunku, nie wynika, iż są wyrazem wzrostu albo mają charakter regresywny. Tego rodzaju interpretacja jest konsekwencją często ukrytych założeń na temat rozwojowego/ regresywnego kierunku zmian, wcześniejszych niż stwierdzone fakty zmienności.

Porządek teleologii występuje w sposób najbardziej wyartykułowany w wypadku kryterium ukierunkowania zmian, zakładającego jakąś kulminację, zwieńczenie rozwoju. Perspektywa teleologii stawia pod znakiem zapytania obiektywność wymienionych kryteriów, ponieważ ukierunkowanie na cel zakłada zawsze perspektywę kogoś, kto ten cel wyznacza, oraz ujmuje fakty powiązane $\mathrm{w}$ relacje przyczynowo-skutkowe w kontekst intencji, celów, zamiarów, który implikuje coś więcej niż same te relacje. Najważniejsze implikacje porządku teleologii to normatywność i atrybucja funkcjonalna. Ta pierwsza umożliwia ujęcie faktów przyczynowo-skutkowych w ramy norm i typowych wzorów, pozwalających oceniać rozwój jako prawidłowy. Ta druga nadaje funkcjonalny sens sekwencji zmian jako pozwalających osiągnąć jakiś punkt docelowy w rozwoju (np. mądrość, samorealizację), albo istotny jego standard (adaptację, koherencję itd.) W tym sensie psychologowie rozwojowi mogą mówić o prawidłowym rozwoju (gdy zmiany przebiegają zgodnie z założoną sekwencją w przewidywanym kierunku) oraz realizacji przyjętej funkcji rozwoju (gdy osiągana jest kulminacja rozwoju). Na przykład funkcją rozwoju mowy jest osiągnięcie przez jednostkę pełni kompetencji przeciętnego dorosłego użytkownika języka, którym posługuje się otoczenie jednostki. Rozwój przebiega w sposób prawidłowy, gdy obejmuje typowe dla naszego gatunku etapy następujące po sobie w stałym, niezmiennym w swym charakterze rytmie.

Większość proponowanych kryteriów da się wyrazić w postaci dwubiegunowych opozycji: jakościowe/ilościowe, ciągłe/skokowe, ukierunkowane/nieukierunkowane, funkcjonalne/ strukturalne itd. Warto podkreślić, że wybór jednego lub drugiego bieguna owych opozycji jako wskaźnika rozwojowego lub nierozwojowego charakteru zmiany, albo uznanie ich za irrelewantne, jest kwestią przyjętych przez badacza założeń na temat natury tego, co jest przedmiotem/podmiotem procesu rozwoju, a nie samego procesu rozwoju. Można odnieść wrażenie, że zasadniczym źródłem problemów, przed jakimi staje badacz rozwoju, nie jest zatem samo pojęcie rozwoju, ale własna konceptualizacja tego, co się rozwija.

Znaczenie tego rozróżnienia jest jeszcze wyraźniejsze, gdy badacz próbuje identyfikować mechanizmy leżące u podstaw zmiany rozwojowej. Pole dyskusji na ten temat otwierają różnice w poglądach zwolenników paradygmatu mechanistycznego, organizmicznego i kontekstualistycznego (Brzezińska, 2000; Lerner, 2002; Overton, 2006; Pepper, 1942; Trempała, 2000) odnośnie do tego, co sprawia, że system się zmienia (rozwija). W wypadku każdego z wymienionych paradygmatów odpowiedź na to pytanie jest nieco inna.

Według najczęściej powielanych na gruncie psychologii rozwojowej interpretacji różnice między nimi ujmuje się, ogólnie mówiąc, następująco (Brzezińska, 2000; Trempała, 2000):

- Dla podejścia mechanicystycznego charakterystyczny jest swoisty redukcjonizm oraz symplicyzm w ujęciu systemu, który 
się zmienia, oraz jego uwarunkowań, co znajduje swój wyraz w sprowadzaniu złożonych relacji między organizmem i jego otoczeniem do prostych związków i asocjacji między bodźcami a reakcjami. W tym paradygmacie podkreśla się często ilościowy charakter zmiany rozwojowej oraz zasadniczą rolę środowiska zewnętrznego w kształtowaniu procesu rozwoju.

- Z kolei w organicyzmie zwraca się szczególną uwagę na potrzebę całościowego ujęcia systemu, który się zmienia, oraz uwypukla się rolę wewnętrznie (endogennie) usytuowanych źródeł i czynników rozwoju. Charakterystyczne dla tej perspektywy jest również rozumienie zmiany jako jakościowej transformacji układu (systemu), stanowiącej podstawę do ujmowania rozwoju w kategoriach wyraźnie odrębnych stadiów, z których każde cechuje się swoistą organizacją całości.

- W paradygmacie kontekstualizmu natomiast dostrzega się złożony i wielowymiarowy charakter interakcji między rozwijającym się systemem (zachowaniem, psychiką, emocjami, inteligencją itd.) a kontekstem jego funkcjonowania. W tym ujęciu podkreśla się heurystyczną wartość relacyjnego i wielopoziomowego ujęcia zarówno związków między rozwijającym się systemem a jego otoczeniem, jak i mechanizmów leżących $\mathrm{u}$ podstaw procesu zmian, którym podlega system oraz jego otoczenie.

Można zatem zaryzykować tezę, że przedmiotem wymienionych paradygmatów nie jest rozwój, ale to, co zakładamy, że się rozwija. Każdy paradygmat w specyficzny dla siebie sposób ujmuje system (układ zachowania, psychikę), który się zmienia, jak również uwarunkowania i mechanizmy leżące u podstaw tych zmian. Warto zwrócić uwagę, że w zaprezentowanym rozumieniu sensu wymienionych paradygmatów to nie rozwój okazuje się pojęciem problematycznym - nie staje się powodem dla ich wyróżniania, ponieważ to, czy występuje czy nie, jest (jak się przyjmuje) kwestią jedynie empiryczną i w gruncie rzeczy łatwą do obiektywnego zweryfikowania. Inaczej mówiąc, rozwój $\mathrm{w}$ tym rozumieniu jest pojęciem intuicyjnym (concept by intuition), dającym się wywieść $\mathrm{z}$ faktów, pojęciem denotującym coś, co może być bezpośrednio pojęte (immediately apprehended) (Northrop, 1947). Problematyczne okazują się natomiast: natura tego, co się zmienia, oraz czynniki, które te zmiany warunkują. To sprawia, że zarysowują się cechy charakterystyczne dla tych paradygmatów, a w konsekwencji różnice między nimi. Problemem nie jest odpowiedź na pytanie, czym jest sama zmiana rozwojowa, ale jaki jest mechanizm zmiany, o której zakładamy, że jest rozwojowa, albo jakie czynniki ją wywołują. Problemy te wydają się często nierozstrzygalne (natura/kultura, dojrzewanie/ uczenie, geny/środowisko) i uzasadniają rację bytu owych paradygmatów.

Tymczasem warto odwrócić tę perspektywę i przyjąć, że problematyczne - a przynajmniej w większej mierze - jest samo pojęcie rozwoju, a nie koncepcje dotyczące natury zmieniającego się układu czy też mechanizmów, czynników i uwarunkowań tych zmian. Na pytania o to, co wywołuje zmianę, jakie są jej uwarunkowania, czy zmiana jest konsekwencją uczenia czy dojrzewania, niewątpliwie często trudno znaleźć odpowiedź, niemniej są to zawsze pytania empiryczne. Nie podlega natomiast konfrontacji z faktami i nie wydaje się oczywisty rozwojowy sens tej zmiany, a więc samo pojęcie rozwoju, ponieważ zakłada ono zawsze interpretację faktów zmienności wcześniejszą niż same te fakty.

Bernard Kaplan (1983a) przedstawił interesującą propozycję odwrócenia tej perspektywy, wyraźnie oddzielając pojęcie rozwoju od pojęcia ontogenezy. W jego ujęciu ontogenezę należy rozumieć jako sekwencję faktów zmienności w dziedzinie zachowania i psychiki człowieka, którą w procesie badania można ująć w związki przyczynowo-skutkowe. Pojęcie rozwoju natomiast należy wiązać wyłącznie z interpretacją tych sekwencji, pozwalającą nadać im rozwojowy sens w świetle przyjętej koncepcji tego, czym rozwój w istocie jest. Kaplan nieco metaforycznie ujmuje relację między ontogenezą i rozwojem w kategoriach ,aktualizacji tego, co idealne", (actualization of the ideal). To, co idealne, jest wyrazem ujęcia faktów zmienności zachowania i psychiki w perspektywie teleologicznej, zakładającej 
określoną koncepcję rozwoju z kluczowymi dla niej kategoriami normy i wartościowania. Te kategorie pozwalają zdefiniować wartościowe stany rzeczy w procesach zmienności zachowania i psychiki, a w konsekwencji - określić prawidłowe (prowadzące do wartościowych stanów rzeczy) i nieprawidłowe (te, które tego nie czynią) przebiegi procesów zmienności zachowania i psychiki. Miarą aktualizacji ideału jest zatem stopień, w jakim charakter zmian ontogenetycznych mu odpowiada.

Kaplan (1983a, 1983b) określa perspektywę teleologiczną mianem perspektywy genetycznej. Jej dopełnieniem jest perspektywa dramatyczna, którą można wyrazić metaforycznie jako,,idealizacja tego, co aktualne" (idealization of the actual). Kaplan w tej części swojej propozycji ujęcia problematyki rozwoju człowieka wpisuje się w teoretyczno-badawczy nurt psychologii narracyjnej, który proponuje specyficzny sposób konceptualizacji zachowania i psychiki oparty na metaforze narracji (Bruner, 1991; Sarbin, 1986). W opinii zwolenników tego podejścia w psychologii język narracji - zakładający w warstwie formalnej uniwersalny w swym charakterze system kategorii: podmiotu, działania oraz celu, środków i okoliczności, w jakich ono przebiega (Burke, 1969) - jest jedynym możliwym sposobem nadania sensu doświadczeniu w jego wymiarze aktualnym, retro- i prospektywnym, zrozumiałym dla jednostki (Ricoeur, 1990). Według Kaplana jest to alternatywny do propozycji behawiorystycznych, psychodynamicznych oraz poznawczych sposób ,idealizacji tego, co aktualne", a więc konceptualizacji języka teoretycznego opisu surowych faktów z obszaru zachowania człowieka. Rozwinięciem obu tych rozróżnień jest jego koncepcja perspektywy genetyczno-dramatycznej w badaniu rozwoju człowieka (Kaplan, 1983a).

W naukowych próbach ujęcia rozwoju to badacz, będąc zakorzeniony w pewnym typie dyskursu naukowego oraz tradycji rozumienia rozwoju, określa język teoretycznego opisu i interpretacji faktów, które nie mówią same za siebie (gdyż w jakim języku miałyby mówić?). Odwołując się do wybranego paradygmatu, proponuje specyficzną rozwojową interpretację tych faktów. Należy podkreślić, że zasada ta obowiązuje również wtedy, gdy chodzi o osobiste, wyrażone w postaci prywatnych teorii rozwoju, próby jego zrozumienia. W obu wypadkach sytuacja jest analogiczna. Według Anthony'ego Giddensa (1993) badacz procesów społecznych, podobnie jak zwykły użytkownik języka, znajduje się w szczególnej sytuacji, ponieważ rzeczywistość społeczna i psychologiczna jest podwójnie hermeneutyczna. Interpretację zakłada nie tylko nierozerwalny związek faktów i języka ich teoretycznego opisu, z czym mamy do czynienia również w przyrodoznawstwie. W wypadku nauk społecznych interpretacja jest także obecna na bardziej podstawowym poziomie - zdobywania faktów. Chodzi o to, że badacz tej dziedziny rzeczywistości nie może się posługiwać językiem jak narzędziem neutralnym. Usiłuje bowiem badać obiekty, które w istotny sposób w języku i poprzez język zostały wykreowane (Giddens, 1993; Habermas, 2004).

Idea ta staje się motywem przewodnim konstruktywizmu społecznego. Wyraża ją w sposób bardzo charakterystyczny stanowisko, jakie zajmuje np. Kenneth Gergen (1997). Jego zdaniem naukowa wiedza psychologiczna nie jest odbiciem rzeczywistości psychologicznej, ale pochodną określonych praktyk językowych i społecznych, dyskursu naukowego. W sensie logicznym okazuje się zależna, a więc konstytuowana przez te praktyki. Zmienia się stosownie do zmian, jakim one podlegają. Może być oceniana jedynie w kategoriach koherencji wewnętrznej, a nie prawdy czy fałszu. W tym sensie teorie psychologiczne nie poddają się empirycznej weryfikacji, ponieważ nie opisują i nie wyjaśniają żadnych faktów, nie wychodzą poza język, w jakim są sformułowane.

Nie podejmując $w$ tym miejscu wątku statusu ontologicznego rzeczywistości psychologicznej oraz nie rozstrzygając tej kwestii w sposób tak zdecydowany, jak czyni to Kenneth Gergen, warto jednak wskazać ograniczoność perspektywy, którą określić można jako scjentystyczna i która niewątpliwie dominuje obecnie w dziedzinie refleksji i badań nad rozwojem człowieka. Wyrazem jej słabości jest, jak się wydaje, niedostrzeganie złożoności samego pojęcia rozwoju i jego specyficznej natury. 
W postulowanym w niniejszym tekście znaczeniu rozwój nie jest pojęciem empirycznym, ale teoretycznym, definiowanym w kontekście określonej teorii (concept by postulation) (Northrop, 1947), a więc jest zawsze formą interpretacji faktów zmienności, jakiej podlega system (układ), np. taki jak zachowanie czy psychika człowieka. Ponieważ interpretacja ma zawsze swojego autora, dokonywana jest w jakiejś perspektywie, ma w konsekwencji on tologi ę pierwszoosobową, a nie trzecioosob ow ą (Searle, 1999).

Warto zwrócić uwagę, że proponowane w niniejszym tekście rozumienie rozwoju, zakładające wielość możliwych interpretacji faktów zmienności zachowania i psychiki człowieka, dobrze odpowiada metaforze rdzennej kontekstualizmu w ujęciu zaproponowanym przez Stephena Peppera (1942), które - jak się wydaje - nie do końca pokrywa się z dominującą we współczesnej psychologii life-span wykładnią kontekstualizmu. Poniższy cytat oddaje sens tej metafory:

Najlepszym określeniem potocznym, które wskazuje na punkt wyjścia kontekstualizmu, jest prawdopodobnie wydarzenie w jego wymiarze historycznym. W ten sposób konsekwentnie określać będziemy metaforę rdzenną owego paradygmatu. Kontekstualista, mówiąc o wydarzeniu historycznym, nie ma jednak na myśli przede wszystkim faktu z przeszłości, który jest martwy i może być jedynie ekshumowany. Ma raczej na myśli fakt żywy w jego wymiarze teraźniejszym. Zazwyczaj pojmujemy historię - mówi kontekstualista - jako próbę uczynienia ponownie aktualnymi (re-present) faktów z przeszłości, ożywienia ich w pewien sposób. Prawdziwe wydarzenie historyczne, w jego teraźniejszości oraz wymiarze dynamicznym, dramatycznym oraz aktywnym, istnieje wtedy, gdy się rozgrywa, czyli teraz. Jeśli tego chcemy, możemy je nazwać aktem (act) [...]. Nie mamy jednak na myśli aktu izolowanego, wykrojonego $\mathrm{z}$ tła; to akt ujmowany razem $\mathrm{z}$ jego otoczeniem, w kontekście (Pepper, 1942, s. 232).

Pepper, wyjaśniając istotę kontekstualizmu, zwraca uwagę na kluczową dla tej teorii kate- gorię ontyczną, którą jest z mian a. Pozwala ona odczytać właściwy sens metafory rdzennej kontekstualizmu. „Wydarzenie w wymiarze historycznym" nie ma jednej prawdziwej wykładni, a fakt historyczny nie ma charakteru wiernego recytatywu z przeszłości. Przeciwnie, jest zawsze czymś żywym i ,prawdziwym” w kontekście perspektywy, w jakiej jest ujmowany. Podobnie rozwój i jego konceptualizacja są zawsze rezultatem kreacyjnej funkcji umysłu, obdarzonego cechą świadomości i intencjonalności. Dobitnym tego przykładem okazuje się proliferacja $\mathrm{w}$ zakresie rzeczywistych, to znaczy naukowych, zarazem bardziej systematycznych oraz nienaukowych, potocznych, prób ujęcia rozwoju. W odróżnieniu od wielu obiektów należących do rzeczywistości społecznej i instytucjonalnej rozwój zachowania i psychiki człowieka, chociaż stanowi obiekt kolektywnej intencjonalności, nie jest przedmiotem społecznego konsensusu, nie zakłada jednej „właściwej” interpretacji .

Problematyczność pojęcia rozwoju uwidacznia się szczególnie wyraźnie, gdy chcemy odróżnić rozwój od jego przeciwieństwa, a więc regresu. Paradoksem jest to, że wszystkie kryteria stosowane dla oceny rozwojowego charakteru zmiany mogą być użyte dla oceny zmiany o charakterze regresywnym, a zarazem żadne z nich, w gruncie rzeczy, nie pozwala odróżnić rozwoju od regresu. Na przykład proces inwolucji, atrofii, rozpadu organizacji zachowania i psychiki, znajdujący swój wyraz w chorobie Alzheimera czy w wielu innych przypadkach tego rodzaju, da się ująć w kategoriach wszystkich tych kryteriów. To, że odczytujemy go jako wyraz regresu, wynika ze społecznego w swej naturze faktu, że cenimy życie i zdrowie, a boimy się choroby i śmierci.

Wygląda na to, że coś jest rozwojem albo regresem tylko i wyłącznie dlatego, że za taki go uważamy. Stwierdzenie rozwoju (regresu) ma zawsze charakter sądu wartościującego, a nie opisowego, w związku z czym nie można ocenić, czy jest prawdziwy, czy jest fałszywy, przez odniesienie do faktów. Kryterium prawdy może stanowić raczej spójność z przyjętą koncepcją rozwoju (regresu). Przez odwołanie do jakiegoś standardu, normy, ideału rozwoju (regresu) sąd 
wartościujący pozwala ująć sekwencję zmian w kategoriach jednego albo drugiego. Ten sposób rozumienia rozwoju wprost nawiązuje do koncepcji Johna R. Searle'a natury rzeczywistości społecznej i instytucjonalnej oraz jego teorii umysłu (Searle, 1999).

Przyjrzyjmy się zatem ujęciu rozwoju w perspektywie koncepcji Searle'a (1999). Podstawę jego propozycji rozumienia natury rzeczywistości i relacji, jaka łączy umysł ze światem, stanowi teza, iż rzeczy w świecie mogą istnieć na dwa sposoby - niezależny i zależny od obserwatora. Wyrazem pierwszego jest podstawowe w swym charakterze przeświadczenie, że świat istnieje niezależnie od naszych o nim wyobrażeń (założenie realizmu zewnętrznego). Drugi sposób istnienia jest natomiast ściśle związany z podstawowymi cechami umysłu człowieka, jakimi są świadomość i intencjonalność. Searle określa ten sposób istnienia rzeczy jako ,zależny od obserwatora" w przeciwieństwie do pierwszego sposobu istnienia, który jest „niezależny od obserwatora".

Według Searle’a (1999) do rzeczywistości zależnej od obserwatora należy niewątpliwie wszystko to, co społeczne oraz instytucjonalne. Gdy zastanawiamy się nad naturą takich rzeczy, jak rządy, sądy, banki, pieniądze, krzesła, stwierdzamy, że są tym, czym są, na mocy tego, że za takie je uznajemy. Co więcej, bez udziału ludzkiej świadomości oraz intencjonalności wszystkie te rzeczy przestałyby istnieć w ich społecznym oraz instytucjonalnym znaczeniu. Tezą niniejszych rozważań jest przekonanie, że pojęcie rozwoju należy do sfery tego, co społeczne i instytucjonalne. Podobnie jak w wypadku banków, pieniędzy, granic państwowych itp. rozwój jest tym, czym jest, na mocy tego, że za taki go uznajemy. W świecie niezależnym od obserwatora kategoria rozwoju wydaje się irrelewantna, ponieważ zakłada ona w sposób konieczny porządek teleologiczny w analizie sekwencji zmian, jakim podlega system (zachowanie, psychika człowieka). Porządek tego rodzaju jest pochodną ujęcia rzeczywistości w języku celów (zamiarów) oraz instrumentów (środków) służących ich realizacji. Teza przeciwna wymagała przekonania, że zmiany, jakie rejestrujemy w świecie niezależnym od obserwatora, mają swój cel i mają swoją wartość z punktu widzenia jakiegoś obiektywnego, idealnego wzorca biegu wydarzeń w tym świecie (Hofstadter, 1941). W kontekście teorii Searle'a takie przekonanie okazuje się pozbawione sensu.

Powstaje pytanie, w jaki sposób umysł tworzy rzeczywistość zależną od obserwatora. Według wielu badaczy tego zagadnienia jest to pochodna szczególnej cechy świadomości, którą jest intencjonalność, czyli zdolność umysłu do odnoszenia się do świata oraz tworzenia jego reprezentacji (Brentano, 1999; Searle, 1999; Krokos, 2013). Interesujące wydaje się to, że różne rodzaje treści intencjonalnych są powiązane ze światem poprzez różne rodzaje stanów intencjonalnych. Istotny z punktu widzenia owego powiązania jest kierunek odpowiedniości między zawartością zdaniową stanu intencjonalnego a światem (Anscombe, 1957; Austin, 1953). Będzie on inny w wypadku zdań afirmujących, przekonań, hipotez, a inny w odniesieniu do pragnień, życzeń, zamiarów. W wypadku tych pierwszych uznaje się je za prawdziwe, gdy zgadzają się z tym, co rzeczywiste - to umysł musi mieć prawdziwy obraz realnie istniejącego świata. Kierunek odpowiedniości wówczas można wyrazić w postaci relacji od umysłu do świata. W wypadku tych drugich kierunek odpowiedniości jest dokładnie odwrotny - od świata do umysłu; aby pragnienia, życzenia, zamiary mogły być zrealizowane, spełnione (a nie prawdziwe, jak w kognitywnych stanach intencjonalnych), świat musi być dostosowany do tego, co jest ich treścią (relacja ś w i a t-u m y s ł). Rozróżnienie tych trzech atrybutów stanów intencjonalnych (typu, zawartości treściowej oraz kierunku odpowiedniości między umysłem a światem) pozwala poszerzyć spektrum relacji, jakie łączą umysł i świat. Kategoria prawdy nie jest jedynym określeniem, które oddaje charakter tych związków. Searle proponuje pojęcie warunków fortunności, takich jak warunki prawdziwości (przekonania, spostrzeżenia, wspomnienia) albo warunki spełnienia (pragnienia) bądź warunki zrealizowania (zamiary, plany), które mają inny charakter dla różnych typów stanów intencjonalnych (Searle, 1999). 


\section{IMPLIKACJE METODOLOGICZNE}

Jeżeli rozwój jest tym, czym jest, na mocy tego, że za taki go uznajemy, to powstaje pytanie, jak można w sposób naukowy, a więc obiektywny, badać rozwój, skoro okazuje się ufundowany na gruncie subiektywnych w swym charakterze przeświadczeń, że jest tym, za co go uznajemy. Parafrazując Searle'a, można zapytać: jak badać i analizować w sposób epistemologicznie obiektywny coś, co stanowi konsekwencję ontologicznie subiektywnych przekonań, że jest tym, czym jest? Zazwyczaj pojęcie subiektywności trudno pogodzić $\mathrm{z}$ naukowością. $Z$ tego m.in . powodu introspekcji nie traktuje się w psychologii współczesnej jako metody obiektywnej. Searle zwraca uwage na częsty błąd w rozumieniu pojęcia subiektywności i obiektywności, który prowadzi do tego rodzaju nieuzasadnionych przekonań. Polega on na nieodróżnianiu wymiaru ontologicznego i epistemologicznego opozycji subiektywność-obiektywność. Zazwyczaj uważamy, że gdy coś istnieje w sposób subiektywny, to nie może podlegać obiektywnemu poznaniu. Tymczasem to, że coś ma ontologię pierwszoosobową, a więc istnieje w sposób subiektywny, nie przesądza o braku możliwości jego obiektywnego badania (Searle, 1999).

Jak zatem badać zjawiska tego rodzaju? Jak analizować rozwój, który w proponowanym znaczeniu jest zjawiskiem ściśle powiązanym ze świadomością człowieka oraz jego intencjonalnością? Searle zwraca uwagę na istotny fakt dotyczący intencjonalności naszego umysłu. Z jednej strony dzięki intencjonalności umysł tworzy wewnętrzne reprezentacje obiektów i stanów rzeczy w świecie o różnym kierunku odpowiedniości między umysłem i światem. $Z$ drugiej strony pozostaje on w stałym związku przyczynowym ze światem. Na przykład przedmioty, na które patrzymy, wywołują w nas wrażenia wzrokowe, rzeczywiste zdarzenia z przeszłości przywołują nasze wspomnienia, zamiary są powodem podjęcia działania itd. W każdym wypadku zdolność do tworzenia reprezentacji oraz związki przyczynowe zazębiają się w regularny sposób. Zdaniem Searle'a to szczególne powiązanie wyraża intencjonalny związek przyczynow y, który ma charakter a u t o r e fer e n cyjny, co oznacza, że w zależności od kierunku odpowiedniości między światem a umysłem skutek jest reprezentacją przyczyny albo na odwrót przyczyna - reprezentacją skutku.

W wypadku tych stanów intencjonalnych, które są interesujące z punktu widzenia analizy rozwoju w proponowanym w niniejszym wywodzie znaczeniu, to znaczy wolity w n ch stanów intencjonalnych, oznacza to, że np. zamiar jest nie tylko reprezentacją swojego warunku fortunności, czyli podjęcia działania, ale jednocześnie jego przyczyną, a dokładniej rzecz ujmując - jedną częścią warunku fortunności zamiaru jest podjęcie działania, a drugą jest fakt, że sam zamiar może wywołać działanie. Związek przyczynowy ma tutaj kierunek od umysłu do świata, a odpowiedniość - od świata do umysłu. W wypadku intencjonalnych stanów kognityw$\mathrm{ny} \mathrm{ch}$, takich jak spostrzeżenia, wspomnienia, relacje mają one dokładnie odwrotny charakter. Kierunek związku przyczynowego wyraża relacja świat-umys 1, a kierunek odpowiedniości - u m y s 1-ś w i a t. Searle utrzymuje, że pojęcie intencjonalnego związku przyczynowego jest niezbędne do wyjaśnienia i zrozumienia ludzkiego zachowania. Pozwala ono bowiem ująć relację między przyczyną a zachowaniem jednocześnie w kategoriach związku przyczynowo-skutkowego oraz logicznego.

Aparat pojęciowy, który proponuje Searle do analizy stanów intencjonalnych, może być interesujący i użyteczny dla badacza rozwoju człowieka $\mathrm{z}$ wielu powodów, ale jeden z nich wydaje się szczególnie istotny - ma on określone konsekwencje metodologiczne. Wprowadza bowiem w obszar metodologii badań nad rozwojem człowieka w sposób jednoznacznie wyartykułowany idiom intencjonalny, który nie mieści się w pozytywistycznym i neopozytywistycznym paradygmacie nauki, do którego tak chętnie psychologia się odwołuje.

Współczesna psychologia rozwojowa w swym głównym nurcie zdaje się nie dostrzegać sprzeczności między ujmowaniem człowieka jako podmiotu własnego rozwoju, zatem istoty świadomie (przynajmniej w dorosłym 
okresie swojego życia) określającej jego kierunek i naturę ( $\mathrm{z}$ tym sposobem ujęcia można się zapoznać w takich pracach, jak: Jančina, Kubicka, 2014; Lerner, Bush-Rossnagel, 1981; Niemczyński, 1980, 1994; Pietrasiński, 1990) a szczególnym waloryzowaniem w dziedzinie standardów metodologicznych tych strategii badawczych, które w istocie nie pozwalają w sposób właściwy ująć intencjonalności w analizie ludzkiego zachowania i psychiki. Ta sprzeczność znajduje swój wyraz również w niektórych próbach konceptualizacji głównych czynników i uwarunkowań rozwoju, w których autonomia i podmiotowość człowieka w regulacji jego rozwoju są pomijane (Baltes, Lindenberger, Staudinger, 1998). Oczywiście istnieje tak zwany nurt badań jakościowych w psychologii rozwo- jowej, ale często badania te prowadzone są w paradygmacie neopozytywizmu i logicznego empiryzmu, a nie hermeneutycznej w swym charakterze interpretacji, a nawet gdy mają taki charakter, to traktowane są jako mniej wiarygodne, o mniejszej wartości naukowej.

Wartość propozycji Searle'a polega na próbie pogodzenia dwóch perspektyw w analizie ludzkiego zachowania: porządku przyczyn i skutków należącego do rzeczywistości niezależnej od obserwatora oraz istotnego w analizie rozwoju człowieka, porządku zamiarów, planów i dążeń. Próba ta wpisuje się w rozwijający się nie tylko w obszarze filozofii nauki (Hanson, 1958; Ricoeur, 1989; von Wright, 1971), ale także psychologii (Overton, 2006; Overton, Lerner, 2012) pogląd, że możliwa i pożądana jest integracja tych dwóch porządków.

\section{BIBLIOGRAFIA}

Anscombe E. (1957), Intention. Oxford.

Austin J.L. (1953), How to Talk: Some Simple Ways. Proceedings of the Aristotelian Society, 53, 227-246. Baltes P.B., Lindenberger U., Staudinger U.M. (1998), Life-Span Theory in Developmental Psychology. W: R.M. Lerner (ed.), Handbook of Child Psychology. Vol. 1: Theoretical Models of Human Development, 1029-1143. New York: Wiley.

Brentano F. (1999), Psychologia z empirycznego punktu widzenia. Warszawa: PWN.

Broughton J. (ed.) (1987), Critical Theories of Psychological Development. New York: Springer.

Bruner J.S. (1991), The Narrative Construction of Reality. Critical Inquiry, 18, 1-21.

Brzezińska A. (2000), Społeczna psychologia rozwoju. Warszawa: Wydawnictwo Naukowe Scholar.

Burke K. (1969), A Grammar of Motives. Berkeley: University of California Press.

Burman E. (1994), Deconstructing Developmental Psychology. London, New York: Routledge.

Gergen K. (1997), The Place of the Psyche in a Constructed World. Theory and Psychology, 7, 723-746.

Giddens A. (1993), New Rules of Sociological Method: A Positive Critique of Interpretative Sociologies. Stanford: Stanford University Press.

Habermas J. (2004), Teoria działania komunikacyjnego, t. 1. Warszawa: PWN.

Hanson N.R. (1958), Patterns of Discovery: An Inquiry into the Conceptual Foundations of Science. Cambridge: Cambridge University Press.

Hofstadter A. (1941), Objective Teleology. Journal of Philosophy, 38(2), 29-39.

Hook D. (ed.) (2004), Critical Psychology. Cape Town: UCT Press.

Jančina M., Kubicka D. (2014), Kierowanie własnym rozwojem: kontekst teoretyczny zjawiska. Psychologia Rozwojowa, 19(4), 31-48.

Kaplan B. (1983a), Genetic-Dramatism: Old Wine in New Bottles. W: S. Wapner, B. Kaplan (eds.), Toward a Holistic Developmental Psychology. Hillsdale, NJ: Erlbaum.

Kaplan B. (1983b), A Trio of Trials. W: R. Lerner (ed.), Developmental Psychology: Historical and Philosophical Perspectives, 53-74. Hillsdale, NJ: L. Erlbaum Associates.

Krampen G., von Eye A., Schui G. (2011), Forecasting Trends of Development of Psychology from a Bibliometric Perspective. Scientometrics, 87, 687-694.

Krokos J. (2013), Odstanianie intencjonalności. Warszawa: Liberi Libri. 
Langer, S. (1957), Philosophy in a New Key. A Study in the Symbolism of Reason, Rite, and Art. Cambridge, MA: Harvard University Press.

Langer S. (1976), Nowy sens filozofii. Warszawa: PIW.

Lerner R.M. (2002), Concepts and Theories of Human Development. New York: Random House.

Lerner R.M., Busch-Rossnagel N.A. (eds.) (1981), Individuals as Producers of Their Development: A Life-Span Perspective. New York: Academic Press.

Niemczyński A. (1980), Modele indywidualnego rozwoju człowieka. Kraków: Wydawnictwo UJ.

Niemczyński A. (1994), O autonomii rozwoju. Zarys problematyki. Kwartalnik Polskiej Psychologii Rozwojowej, 2, 3-11.

Northrop F.S.C. (1947), The Logic of the Sciences and the Humanities. New York: Meridian Books, Inc.

Overton W.F. (2006), Developmental Psychology: Philosophy, Concepts, Methodology. W: R.M. Lerner (ed.), Handbook of Child Psychology. Vol. 1: Theoretical Models of Human Development, 18-88. New York: John Wiley \& Sons, Inc.

Overton W.F., Lerner R.M. (2012), Relational Developmental Systems: Paradigm for Developmental Science in Post-Genomic Era. Behavioral and Brain Sciences, 35(5), 375-376.

Pepper S. (1942), World Hypotheses. Los Angeles: University of California Press.

Pietrasiński Z. (1990), Rozwój człowieka dorosłego. Warszawa: Wiedza Powszechna.

Ricoeur P. (1989), Język, tekst, interpretacja. Warszawa: PIW.

Ricoeur P. (1990), Time and Narrative. Chicago, University of Chicago Press.

Sarbin T.R. (ed.) (1986), Narrative Psychology: The Storied Nature of Human Conduct. New York: Praeger.

Schaie K.W., Baltes P.B. (1975), On Sequential Strategies in Developmental Research. Human Development, 18(5), 384-390.

Searle J.R. (1999), Język, umyst, społeczeństwo. Filozofia i rzeczywistość. Warszawa: W.A.B.

Trempała J. (2000), Modele rozwoju psychicznego. Czas i zmiana. Bydgoszcz: Wydawnictwo Naukowe AB. von Wright G.H. (1971), Explanation and Understanding. Ithaca, NY: Cornell University Press. 